\title{
ENDIVIDAMENTO PÚBLICO DE MINAS GERAIS: HISTÓRICO E RECENTES PROPOSTAS DE RECUPERAÇÃO
}

\author{
MINAS GERAIS’S PUBLIC DEBT: HISTORICAL AND RECENT RECOVERY PROPOSALS \\ ENDEUDAMIENTO PÚBLICO DE MINAS GERAIS: HISTORIAL Y RECIENTES PROPUESTAS DE RECUPERACIÓN
}

\section{RESUMO}

Este artigo busca apresentar o processo de endividamento público do Estado de Minas Gerais e as recentes alternativas que vêm sendo propostas para contornar a atual crise financeira. Foi realizada uma pesquisa bibliográfica, documental, descritiva e quantitativa com coleta de dados governamentais públicos. No final de 2016, o governo declarou situação de calamidade financeira e, desde então, vem tendo dificuldades para pagar os salários dos servidores públicos. Em relação às alternativas para superação da crise financeira, verifica-se que nenhuma teve impactos significativos até o presente momento.

PALAVRAS-CHAVE: Finanças públicas, dívida pública de Minas Gerais, alternativas de financiamento, deficit público, crise financeira.

Paula Guelman Davis ${ }^{1}$

paulagdavis94@gmail.com

ORCID: 0000-0001-5003-8785

Isabella Virgínia Freire Biondini²

isabella.freire@fjp.mg.gov.br

ORCID: 0000-0002-0422-7507

${ }^{1}$ Universidade Federal de Minas Gerais, Centro de Pós-Graduação e Pesquisas em Administração, Belo Horizonte, MG, Brasil

${ }^{2}$ Fundação João Pinheiro, Escola de Governo Paulo Neves de Carvalho, Belo Horizonte, MG, Brasil

Submetido 14.06.2018. Aprovado 23.11.2018

Avaliado pelo processo de double blind review. Editores convidados: Arnaldo Mauerberg Jr., José Roberto Afonso e Sol Garson.

DOI: http://dx.doi.org/10.12660/cgpc.v23n76.75373 


\section{ABSTRACT}

The purpose of this article is to present the process of public indebtedness of the State of Minas Gerais and the recent alternative proposed to overcome the financial crisis situation, through a bibliographical, documental, descriptive and quantitative research gathering public governmental data. $B y$ the end of 2016, the governor declared a state of financial calamity. Since then, the administration struggles to pay the salaries of public employees. We show that none of the alternatives for overcoming the financial crisis achieved significant results up to the present.

KEYWORDS: Public finances, Minas Gerais' public debt, financing alternatives, public deficit, financial crisis.

\section{RESUMEN}

Este artículo busca presentar el proceso de endeudamiento público del Estado de Minas Gerais y las recientes alternativas que vienen siendo propuestas para mejorar la actual crisis financiera a partir de una investigación bibliográfica, documental, descriptiva y cuantitativa con la recolección de datos gubernamentales públicos. A fines de 2016, el gobierno se declaró en situación de calamidad financiera y, desde entonces, ha tenido dificultades para pagar los salarios de los funcionarios públicos. Con relación a las alternativas para superar la crisis financiera, se verifica que ninguna tuvo impactos significativos hasta el presente momento.

PALABRAS CLAVE: Finanzas públicas, deuda pública de Minas Gerais, alternativas de financiamento, déficit público, crisis financeira.

\section{INTRODUÇÃO}

Nos últimos anos, a sustentabilidade das contas públicas tornou-se um desafio comum a todos os entes governamentais. $\mathrm{O}$ crescente endividamento engessa os orçamentos públicos e, assim, os Estados não conseguem cumprir os compromissos assumidos e, ao mesmo tempo, investir e atender às demandas da população. Dado esse cenário, a dívida pública acaba se tornando um gargalo para o desenvolvimento das ações governamentais, afetando diretamente os cidadãos. Sua administração inadequada pode levar a um círculo vicioso de geração de dívida e dependência de financiamentos, normalmente decorrentes da contratação de operações de crédito (OC), que correspondem a receitas no presente e a dívidas no futuro, gerando um ônus para as gerações futuras.

Desde os anos 1990, Minas Gerais convive com cenários de desequilíbrio fiscal e endividamento, com juros e encargos cada vez maiores, orçamento limitado e busca de meios de financiamento. A significativa contratação de OC a partir de 2005 contribuiu para o aumento dos investimentos. No entanto, se esses empreendimentos não gerarem retorno dentro de 10 ou 20 anos, momento em que se deve começar a pagar o financiamento adquirido, o Estado não conseguirá superar a dívida contraída e terá que se endividar mais com o objetivo de pagar os gastos correntes.

Assim, considerando a situação de calamidade financeira decretada pelo governador no final de 2016, é importante entender como se deu o processo de endividamento e buscar algumas razões para Minas Gerais ter entrado em colapso. Este artigo pretende identificar os motivos que levaram à insustentabilidade das contas públicas de Minas Gerais e verificar se as ações tomadas tendem a produzir algum efeito positivo para a melhora dos resultados fiscais, por meio de uma pesquisa quantitativa sobre a sustentabilidade das contas do Estado. 
Quanto aos objetivos, trata-se de uma pesquisa descritiva, uma vez que expõe características da dívida pública de Minas Gerais. Ela envolve a organização e padronização dos dados contidos em relatórios específicos sobre as finanças públicas do Estado elaborados pela Superintendência Central de Contadoria Geral e publicados no site da Secretaria de Estado de Fazenda de Minas Gerais (SEF), conforme mostra a Figura 1.
No que se refere aos procedimentos técnicos, é uma pesquisa bibliográfica, já que é um estudo sistematizado desenvolvido com base em livros, sites, material acessível ao público, sendo instrumento para outros tipos de pesquisa, uma vez que recuperou a discussão sobre dívida pública. Pode ser classificada também como pesquisa documental, pois analisa dados elaborados pela SEF antes de qualquer outro tratamento analítico.

\section{Figura 1. Relatórios contábeis e orçamentário-financeiros, Minas Gerais,} 2018

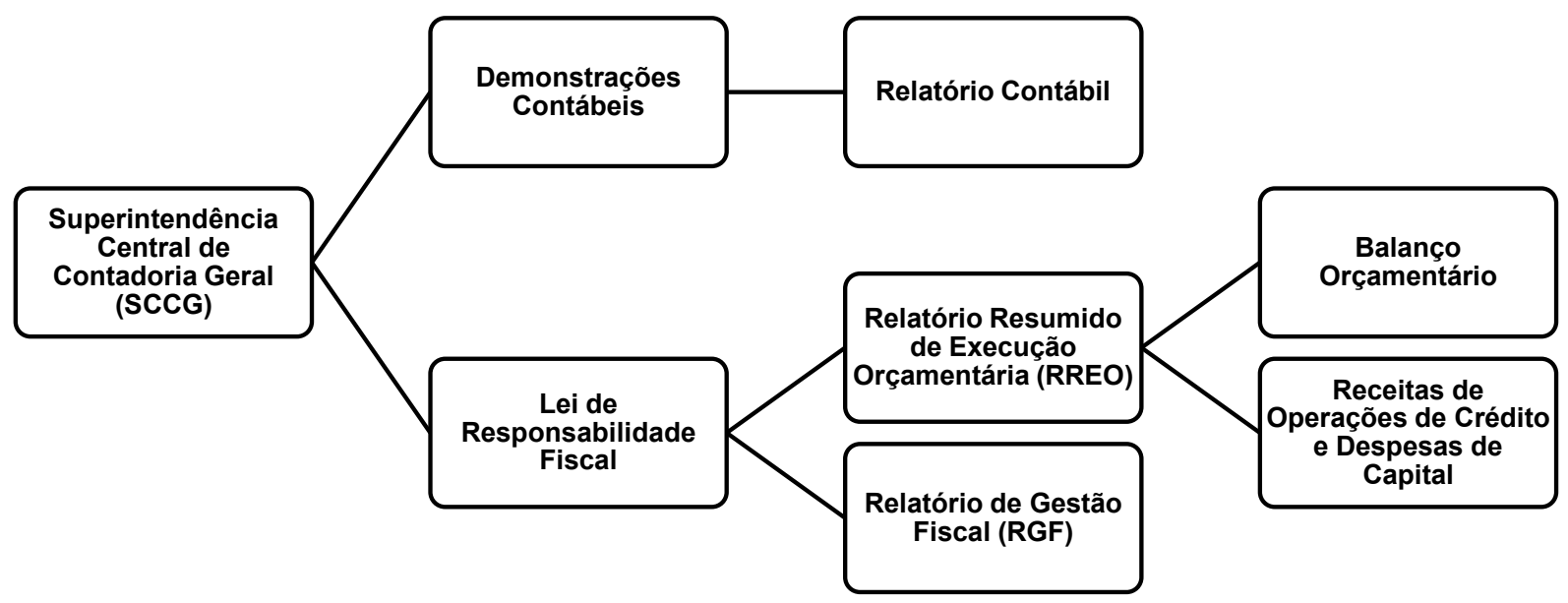

Fonte: Site da Secretaria de Estado de Fazenda de Minas Gerais.

Cada um desses relatórios possui uma periodicidade de publicação diferente. Os relatórios contábeis, que constituem uma parte das demonstrações contábeis, são publicados anualmente. Já os relatórios de cumprimento com as determinações da LRF são publicados mais frequentemente: os RREOs, a cada bimestre, e os RGFs, a cada quadrimestre. Ambos acumulam as informações do ano, isto é, o último relatório contém informações relativas ao ano todo.

\section{DÍVIDA PÚBLICA: CONCEITOS E CLAS- SIFICAÇÕES}

Segundo Mendonça (2005), a dívida pública é gerada a partir de algum desequilíbrio no lado real da economia. Quando a despesa pública é maior do que a receita pública, o governo acaba incorrendo em deficit fiscal, que alimenta o estoque da dívida. Isso acaba gerando uma necessidade de financiamento junto ao setor privado ou a instituições financeiras públicas (Rezende, 2012). 
No Brasil, o cálculo do deficit público é feito pelo Banco Central e pela Secretaria do Tesouro Nacional (STN). São consideradas três modalidades de deficit: (1) o deficit primário, que inclui receitas e despesas não financeiras, excluindo o pagamento de juros; (2) o deficit operacional, dado pela soma do resultado primário com as despesas com juros reais, excluída a inflação; e (3) o deficit nominal, que representa a totalidade do deficit do setor público, registrando todas as receitas e despesas (Matias-Pereira, 2017).

Considerando esses conceitos, Silva, Carvalho e Medeiros (2009) conceituam dívida pública como um compromisso de uma entidade com terceiros, pelo desequilíbrio entre receitas e despesas. O serviço da dívida, por sua vez, é composto pelas amortizações de seu capital e pelos encargos financeiros. Devido a esses encargos, o recurso que o ente recebe não é igual, em prazo ou indexação, ao que ele tem que pagar no futuro. Por isso, a gestão da dívida pública acaba se tornando o gargalo da sustentabilidade de muitos governos. Ela condiciona a capacidade de gasto público e a necessidade de gerar receitas públicas, causando impactos em variáveis econômicas como crescimento, juros, inflação, entre outras (Mendonça, 2005).

A classificação mais conhecida para a dívida pública distingue as dívidas bruta e líqui- da (Silva et al., 2009). A primeira considera somente os passivos do governo, e pode ser contratual ou mobiliária (quando for gerada por meio da emissão de um título). A segunda, por sua vez, desconta desses passivos os ativos que o governo possui.

A Dívida Líquida do Setor Público (DLSP) considera o total das obrigações do setor público não financeiro, que inclui as dívidas internas e externas (tanto mobiliárias quanto contratuais), os compulsórios, as operações compromissadas e a base monetária, subtraindo-se seus ativos financeiros junto aos agentes privados não financeiros e financeiros, públicos e privados. É o conceito mais utilizado para acompanhar a sustentabilidade fiscal de um ente, auxiliando na tomada de decisões de políticas econômicas (Silva et al., 2009).

A Dívida Fiscal Líquida (DFL) corresponde à DLSP, subtraindo-se o efeito dos passivos contingentes (reconhecidos e contabilizados) das receitas de privatização e de outros itens que influem no estoque da dívida no período em análise, mas não representam fluxos de esforço fiscal. A variação da DFL corresponde ao resultado fiscal nominal (Silva et al., 2009).

A Lei Complementar no 101 de 2000 (Lei de Responsabilidade Fiscal, LRF), traz alguns conceitos em relação à divida pública em seu artigo 29 (Quadro 1). 
ENDIVIDAMENTO PÚBLICO DE MINAS GERAIS: HISTÓRICO E RECENTES PROPOSTAS DE RECUPERAÇÃo

Quadro 1. Quadro-resumo dos conceitos apresentados no artigo 29 da Lei Complementar no 101/2000 (Lei de Responsabilidade Fiscal), Brasil, 2001

\begin{tabular}{|l|l|}
\hline Conceito & Definição \\
\hline $\begin{array}{l}\text { Dívida Pública Consoli- } \\
\text { dada ou Fundada }\end{array}$ & $\begin{array}{l}\text { Montante de obrigações financeiras do ente da Federação, assumidas } \\
\text { por: lei, contrato, convênio ou tratado; inclui operações de crédito com } \\
\text { prazo superior a 12 meses. }\end{array}$ \\
\hline $\begin{array}{l}\text { Dívida Pública Mobili- } \\
\text { ária }\end{array}$ & $\begin{array}{l}\text { Representada por títulos emitidos pela União, inclusive os do Banco Cen- } \\
\text { tral, estados e municípios. }\end{array}$ \\
\hline Operação de Crédito & $\begin{array}{l}\text { Compromisso financeiro assumido em função de: mútuo, abertura de cré- } \\
\text { dito, emissão/aceite de título, aquisição financiada de bens, recebimento } \\
\text { antecipado de valores de venda a termo de bens e serviços, arrendamen- } \\
\text { to mercantil e outras, incluindo derivativos financeiros. }\end{array}$ \\
\hline Concessão de Garantia & $\begin{array}{l}\text { Compromisso de adimplência de obrigação financeira ou contratual assu- } \\
\text { mida por ente da Federação. }\end{array}$ \\
\hline $\begin{array}{l}\text { Refinanciamento da } \\
\text { Dívida Mobiliária }\end{array}$ & $\begin{array}{l}\text { Não poderá exceder, ao término de cada exercício: montante final do } \\
\text { exercício anterior + operações de crédito autorizadas/realizadas + atuali- } \\
\text { zação monetária. }\end{array}$ \\
\hline
\end{tabular}

Fonte: Motta e Fernandes (2001, p. 366).

Para os fins deste artigo, ressalta-se o conceito de dívida pública consolidada ou fundada. Trata-se de obrigações financeiras assumidas por meio de contratos de OC com instituições financeiras ou pela emissão de títulos da divida pública que visam atender a obras e serviços públicos. São compromissos de longo prazo, com valor determinado previamente e prazo para amortização superior a 12 meses (Cruz, Vaccari Júnior, Glock, Herzmann \& Tremel 2014).

\section{ESGOTAMENTO DA CAPACIDADE DE FI- NANCIAMENTO DOS ESTADOS}

Ao longo da história do federalismo brasileiro, ocorreram desequilíbrios de poder entre governo central e os entes subnacionais, com prevalência dos interesses da União. A forte centralização do governo federal no período de 1964 até a promulgação da Constituição da República (CR) em 1988 impactou as finanças públicas estaduais (Rezende, Carneiro, \& Rezende, 2014).

No início do governo militar, foram feitas reformas institucionais que determinaram a correção monetária dos títulos públicos, fazendo com que o endividamento se tornasse não só um instrumento de política fiscal e monetária mas também uma fonte de financiamento (Almeida, 1996).

Após 1967, os estados e municípios foram impedidos de criar impostos, de estabelecer alíquotas ou conceder favores ou isenções fiscais sem acordar com os outros entes interessados. Com esse controle da União, os estados passaram a procurar outras fontes de financiamento para que conseguissem ampliar seus gastos e superar a perda de expressão de suas poupanças fiscais e a desproporção na distribuição dos recursos tributários (Silva, 2002). 
No final dos anos 1970, a possibilidade de crédito fácil camuflou o nível de deterioração das finanças públicas, causado pela delicada situação fiscal dos estados e pela incapacidade de reproduzir investimentos e gastos com encargos financeiros sem um fluxo constante e crescente de novos financiamentos (Lopreato, 2002).

A década de 1980 iniciou-se com a suspensão dos fluxos de capital externo para o Brasil, principalmente após a moratória da dívida externa mexicana em 1982. Em um contexto econômico com queda das taxas de crescimento do País e aumento da inflação, a elevação das taxas de juros, a decadência das estruturas de captação e direcionamento dos recursos externos contribuíram para piorar as dificuldades financeiras dos estados (Almeida, 1996).

Mesmo concentrando o poder financeiro e o controle na área fiscal, estava claro o esgotamento da capacidade do governo federal de expandir o sistema de crédito e de sustentar as relações financeiras com os entes federados. Nesse cenário, em 1982, foi estabelecido o primeiro programa econômico patrocinado pelo Fundo Monetário Internacional (FMI), que impediu o uso do endividamento para ampliação dos gastos públicos (Lopreato, 2002).

Após alguns sinais do não cumprimento das metas do acordo pelos governos estaduais, o País recebeu duras críticas do FMI. Isso fez com que a União ampliasse o controle do endividamento desses entes e aumentasse a rigidez em relação às metas destinadas ao setor público. Seguiu-se um período de relativa estabilidade e recupera- ção dos níveis de investimentos, em 1985 e 1986. No entanto, nos anos seguintes, a súbita mudança na perspectiva econômica reverteu a trajetória expansionista e provocou perdas na capacidade de arrecadação dos entes, gerando nova fase de crise financeira para os estados (Lopreato, 2004).

No ano de 1989, ocorreu a primeira rodada de refinanciamento da dívida dos estados. Foi instituída a Lei no 7.976/1989, que dispunha sobre os critérios de rolagem de dívida externa dos entes com prazo de vencimento até 10 de janeiro de 1990. Isso permitiu a regularização das operações por meio de empréstimos-ponte (financiamentos de curto prazo ofertados em situação de emergência) do Tesouro Nacional, que arcavam com a rolagem da dívida externa vencida desses entes (Mora, 2002).

A CR/1988 procurou reduzir a pressão sobre as finanças públicas estaduais. Além de aumentar a base de cálculo do ICMS, principal tributo de competência estadual, ampliou as transferências de recursos pela União. "Em termos de finanças públicas, a assembleia constituinte entendeu que a democracia brasileira necessitava de um governo central fraco e de governos subnacionais fortes" (Dilinger, 1998 citado por Silva, 2002).

Mesmo assim, o quadro de deterioração das finanças estaduais se manteve. Dado esse cenário, após 1994, foram lançadas medidas para controlar as contas públicas e o endividamento dos entes subnacionais (Rezende et al., 2014). O Quadro 2 elenca os principais instrumentos e medidas utilizados pelo governo federal para promover o ajuste fiscal em âmbito nacional. 
ENDIVIDAMENTO PÚBLICO DE MINAS GERAIS: HISTÓRICO E RECENTES PROPOSTAS DE RECUPERAÇÃo

Quadro 2. Medidas adotadas para controlar as finanças e endividamento dos governos subnacionais, Brasil, 1995-2000

\begin{tabular}{|c|c|c|}
\hline Ano & Instrumento & Medidas \\
\hline \multirow[b]{2}{*}{1995} & $\begin{array}{l}\text { Lei Complementar n 82, de } \\
\text { 27/3/95 (Lei Camata I) }\end{array}$ & $\begin{array}{l}\text { Limita em } 60 \% \text { da receita corrente líquida os gastos } \\
\text { com pessoal dos estados e municípios; }\end{array}$ \\
\hline & $\begin{array}{l}\text { Programa de Apoio ao Ajuste } \\
\text { Fiscal dos Estados }\end{array}$ & $\begin{array}{l}\text { Estabelece medidas de controle e redução dos gastos } \\
\text { com pessoal, modernização do sistema fiscal e gera- } \\
\text { ção de informações. }\end{array}$ \\
\hline 1996 & $\begin{array}{l}\text { Programa de Redução do } \\
\text { Setor Público na Atividade } \\
\text { Bancária (PROES) }\end{array}$ & $\begin{array}{l}\text { Condiciona empréstimos para o saneamento dos ban- } \\
\text { cos estaduais à sua privatização e extinção. }\end{array}$ \\
\hline 1997/1998 & $\begin{array}{l}\text { Lei n } 9.496 / 97: \text { estabelece } \\
\text { as condições para a renego- } \\
\text { ciação global da dívida dos } \\
\text { estados }\end{array}$ & $\begin{array}{l}\text { Exige, como contrapartida, compromissos com o ajus- } \\
\text { te fiscal e estabelece condições para a contratação de } \\
\text { empréstimos, praticamente extinguindo, para os gover- } \\
\text { nos subnacionais, a dívida como instrumento comple- } \\
\text { mentar de financiamento. }\end{array}$ \\
\hline 1999 & $\begin{array}{l}\text { Lei Rita Camata II (Lei } \\
\text { Complementar no 96, de } \\
\text { 31/5/1999) }\end{array}$ & $\begin{array}{l}\text { Estabelece o limite de } 50 \% \text { com gastos de pesso- } \\
\text { al em relação à receita corrente líquida para o governo } \\
\text { federal, e de } 60 \% \text { para os estados e municípios; estabelece } \\
\text { vedações para a contratação de pessoal; punições para o } \\
\text { descumprimento dos limites e cronogramas, com prazos de } \\
\text { ajustamento, para o seu alcance. }\end{array}$ \\
\hline 2000 & $\begin{array}{l}\text { Lei Complementar n. 101, de } \\
\text { 4/5/2000 (Lei de Responsa- } \\
\text { bilidade Fiscal) }\end{array}$ & $\begin{array}{l}\text { Estabelece limite de gastos com pessoal, da dívida e } \\
\text { de compromissos dos entes federativos com o equilí- } \\
\text { brio das contas públicas, bem como cronogramas para } \\
\text { os ajustes necessários e punições - administrativas, } \\
\text { prisionais e pecuniárias - nos casos de descumpri- } \\
\text { mento de suas regras. }\end{array}$ \\
\hline
\end{tabular}

Fonte: Oliveira (2007).

Além das medidas mencionadas no Quadro 2, destaca-se a Lei Complementar no 87/1996, chamada de Lei Kandir. Essa lei trouxe mudanças em relação ao ICMS, previsto no artigo 155 da $\mathrm{CR} / 1988$. A principal delas foi "a completa desoneração das operações que destinassem mercadorias ao exterior, alcançando inclusive produtos primários e produtos industrializados semi-elaborados" (Soares, 2007, p. 4).

Por implicar significativa redução da base tri- butável do ICMS, tanto por meio do aumento do número de operações de exportação desoneradas quanto pela maior liberdade de aproveitamento dos créditos do imposto pelos exportadores, o governo federal reconheceu a necessidade de compensar financeiramente os estados. No entanto, as formas de compensação não seguem critérios transparentes, e, por isso, não existe uma consolidação adequada e confiável sobre quanto cada ente perdeu ou ganhou (Soares, 2007). Até hoje, não existe uma norma 
que fixe os valores desses repasses.

A LRF foi promulgada em 2000, num cenário de necessidade de definição de regras de controle fiscal mais restritivas. Ela regulamentou o comportamento dos entes no que diz respeito às finanças públicas, de modo a dar previsibilidade às ações fiscais. $O$ controle do endividamento foi delegado ao Senado Federal, que publicou as Resoluções no 40 e 43 de 2001, promovendo uma melhor definição do novo regime fiscal e mantendo as prerrogativas dos acordos de renegociação da dívida dos anos anteriores. Esse novo regime pretende alcançar a solvabilidade intertemporal das finanças estaduais por meio do estabelecimento de limites de gastos e da redução do endividamento, de modo a manter o equilíbrio fiscal (Lopreato, 2004). Assim, as finanças públicas ficam sujeitas a limites legais para a dívida consolidada, regras para a contratação de OC, parâmetros para alguns tipos de gasto e critérios de contenção do endividamento.

A não resolução da crise financeira dos estados implicou a publicação da Lei Complementar no 159 em 19 de maio de 2017, que altera a LRF e institui o Regime de Recuperação dos Estados e do Distrito Federal. A lei prevê que os estados em situação de calamidade fiscal e insuficiência de caixa podem suspender o pagamento da dívida com a União por três anos. No entanto, antes disso, deverão aprovar leis estaduais que instituam planos de recuperação que devem conter algumas obrigações, como privatizações, e cumprir algumas contrapartidas, como congelamento de salários (Senado Federal, 2017a). Essa questão será aprofundada considerando o contexto de Minas Gerais.

\section{A DÍVIDA PÚBLICA DE MINAS GERAIS: ANTECEDENTES, EVOLUÇÃO E SITUA- ÇÃO ATUAL}

O processo de endividamento de Minas Gerais iniciou-se no século XIX. Em 1897, a Província das Minas Gerais já recorria ao mercado financeiro para financiar políticas para o seu desenvolvimento. Entre 1913 e 1928, Minas foi o primeiro Estado a obter recursos no mercado externo, destinados a financiar o parque ferroviário mineiro. Somente a partir da década de 1960, a administração pública começou a se organizar para criar formas de gerenciamento e controle mais adequadas para as finanças públicas (Riani \& Andrade, 2002).

Nos anos 1990, o Estado já apresentava significativos estoques de dívida. A dívida mobiliária interna sofreu um aumento de 35\% entre 1991 e 1992, e de $81 \%$ entre 1991 e 1994, em razão das altas taxas de juros estabelecidas para a rolagem. A dívida contratual, por sua vez, continuava a ser utilizada como instrumento complementar de financiamento (Riani \& Andrade, 2002).

A dívida mobiliária externa foi contratada em 1994 com taxa de juros de $12 \%$ ao ano e vencimento em 1999 e 2000, por meio da emissão de Bônus do Tesouro Estadual no valor de 200 milhões de dólares, com garantia do Tesouro Nacional. Essa dívida foi quitada no governo de Itamar Franco, em 2000. A dívida contratual externa, por outro lado, voltou a crescer em meados da década de 1990 devido a novas contratações junto a organismos multilaterais: Banco Mundial para a América Latina (BiRD), Banco Interame- 
ricano de Desenvolvimento (BID), Chevron Overseas Petroleum Inc. e Caixa Econômica Federal (Victorino, 2002 citado por Oliveira \& Gontijo, 2012).

O governo de Eduardo Azeredo (1995-1998), dado o cenário financeiro de altos valores de encargos e de uma participação cada vez maior das despesas com pessoal no orçamento, aceitou a proposta da União de refinanciamento de dívidas. No entanto, os acordos celebrados acabaram prejudicando as finanças públicas nos anos seguintes. Em 1996, a despesa com pessoal representava cerca de $90 \%$ da Receita Corrente Líquida (RCL), e a dívida pública, cerca de $24,5 \%$. A relação das OC com as despesas de capital era de $377 \%$. Diante desse contexto financeiro, a administração resolveu transferir o ônus da dívida aos próximos governos a partir de um adiamento do pagamento e privatização de algumas empresas estatais, garantindo a entrada de recursos no Tesouro Estadual (Oliveira \& Gontijo, 2012).

Ainda no início do mandato, o governo celebrou um contrato com a Companhia Energética de Minas Gerais (CEMIG), na qual a empresa transferiria cerca de $\mathrm{R} \$ 600$ milhões para liquidação dos contratos de refinanciamento e amortização parcial do financiamento entre o estado e a União. Estabeleceu-se um período de carência de 36 meses, e a primeira parcela deveria ser paga ao final do mandato (Mateus citado por Freitas, 2014).

Em 1998, foi feita uma nova renegociação da dívida com o governo federal. A União assumiu: (1) a dívida mobiliária no valor de $\mathrm{R} \$ 11,4$ bilhões em Letras Financeiras do Tesouro Estadual (LFTE), existente desde março de 1996 e não paga; (2) os saldos devedores dos contratos acordados com 0 Banco do Brasil e com a Caixa Econômica Federal, que totalizavam $R \$ 332,4$ milhões; e (3) as operações de dívida fundada com instituições financeiras privadas, no valor de R\$ 151,9 milhões (Riani \& Andrade, 2002).

O restante da dívida mobiliária seria paga em 30 anos (360 parcelas), prorrogáveis por mais 10 anos. Foram somados a esse montante financiamentos concedidos pelo governo federal para sanear e privatizar bancos estaduais - Bemge, Credireal, Minascaixa -, além de transformar o Banco de Desenvolvimento de Minas Gerais (BDMG) em agência de fomento (Oliveira \& Gontijo, 2012). Isso resultou na transformação do estoque da dívida mobiliária interna em dívida contratual, que cresceu cerca de $20,3 \%$ em 10 meses (Riani \& Andrade, 2002).

O deficit primário anual de 1998 foi superior a $\mathrm{R} \$ 3,7$ bilhões. Assim, em 1999, Itamar Franco, assumiu o governo e percebeu a grave situação das finanças, intensificada pelo comprometimento da arrecadação de ICMS pela Lei Kandir. Todo esse cenário, somado ao vencimento de parte da dívida transferida pelo governo anterior, levou o governador a declarar moratória da dívida com a União no início de 1999 e iniciar um programa emergencial para controlar gastos governamentais. Além disso, optou por deixar de pagar parcelas previstas no contrato com a Cemig, aumentando cerca de 110,8\% da dívida em termos nominais (Oliveira \& Gontijo, 2012).

O governo seguinte, de Aécio Neves, encontrou o estado em situação menos alarmante. Itamar Franco conseguiu pagar integralmen- 
te a dívida relativa ao 130 salário dos servidores em 2002, contando com a decisão da União de ressarcir o estado em $\mathrm{R} \$ 780 \mathrm{mi}-$ Ihões gastos com manutenção e recuperação das estradas federais que cortam o território mineiro, e também com $R \$ 223$ milhões que seriam liberados pelo governo federal em 2003. Além disso, as receitas do Imposto sobre a Propriedade de Veículos Automotores (IPVA), em torno de R\$350 milhões, contribuiriam para uma melhor administração do fluxo de caixa no início do mandato (Oliveira \& Riani, 2004).

Diante do deficit orçamentário significativo, lançou-se o Choque de Gestão, um programa que visava rever a situação dos deficits fiscais, de modo a possibilitar que o estado voltasse a investir e crescer economicamente (Vilhena, Martins, Marini \& Guimarães, 2006). Além da redução das despesas de custeio, o governo de Minas Gerais: (1) continuou a receber receitas ordinárias devido à manutenção e recuperação das estradas federais; (2) adiou e reduziu o pagamento das dívidas com a Cemig e com a União; e (3) congelou os salários dos servidores. Esses fatores contribuíram para a diminuição do deficit de $\mathrm{R} \$ 2,3$ bilhões para $\mathrm{R} \$ 227 \mathrm{mi}-$ Ihões (Oliveira \& Riani, 2004).

Além disso, a partir de 2004, obtiveram-se ganhos com reformas (tributária, previdenciária e no sistema de taxas) que permitiram que o Estado contasse com recursos para investimento e garantiram o retorno de Minas Gerais para o mercado de crédito em 2005. Em 2009, a RCL sofreu uma redução devido à crise mundial de 2007/2008, que afetou, principalmente, as economias nas quais as commodities têm importância considerável, como é o caso de Minas Gerais (Oliveira \& Gontijo, 2012).

Cabe chamar a atenção, nesse período, para o conceito de deficit zero. Em 23 de novembro de 2004, o governador anunciou que o estado atingiu o equilíbrio orçamentário por meio do cumprimento das leis e regras da boa gestão pública (Secretaria de Estado de Fazenda de Minas Gerais, 2006). No entanto, Oliveira e Gontijo (2012) mostram que o conceito utilizado pelo governo ao fazer esse anúncio foi o de Resultado Orçamentário. O Resultado Orçamentário inclui, junto às receitas públicas, as $\mathrm{OC}$, que constituem uma dívida contratada que deverá ser paga no futuro, portanto não é adequado incluí-la na conta de resultado orçamentário. O Gráfico 1 traz o resultado orçamentário e o montante de OC realizadas por Minas Gerais no período de 2000 a 2017. Pode-se perceber que, em alguns anos, o montante delas foi maior do que o resultado orçamentário, fator decisivo para que o governo obtivesse superavit em 2006 e entre 2009 e 2013.

Em 2011, Antônio Anastasia assumiu o governo do Estado e lançou o Plano Mineiro de Desenvolvimento Integrado (PMDI) 2011 - 2030, no qual ficou estabelecido que as ações do estado seriam organizadas em Redes de Desenvolvimento Integrado. O financiamento dessas redes ocorreu a partir da contratação de OC (Secretaria de Estado de Fazenda de Minas Gerais, 2014) (Gráfico 1). 
Gráfico 1. Resultados orçamentários e montantes de operações de crédito
realizados, Governo do Estado de Minas Gerais, 2000-2017

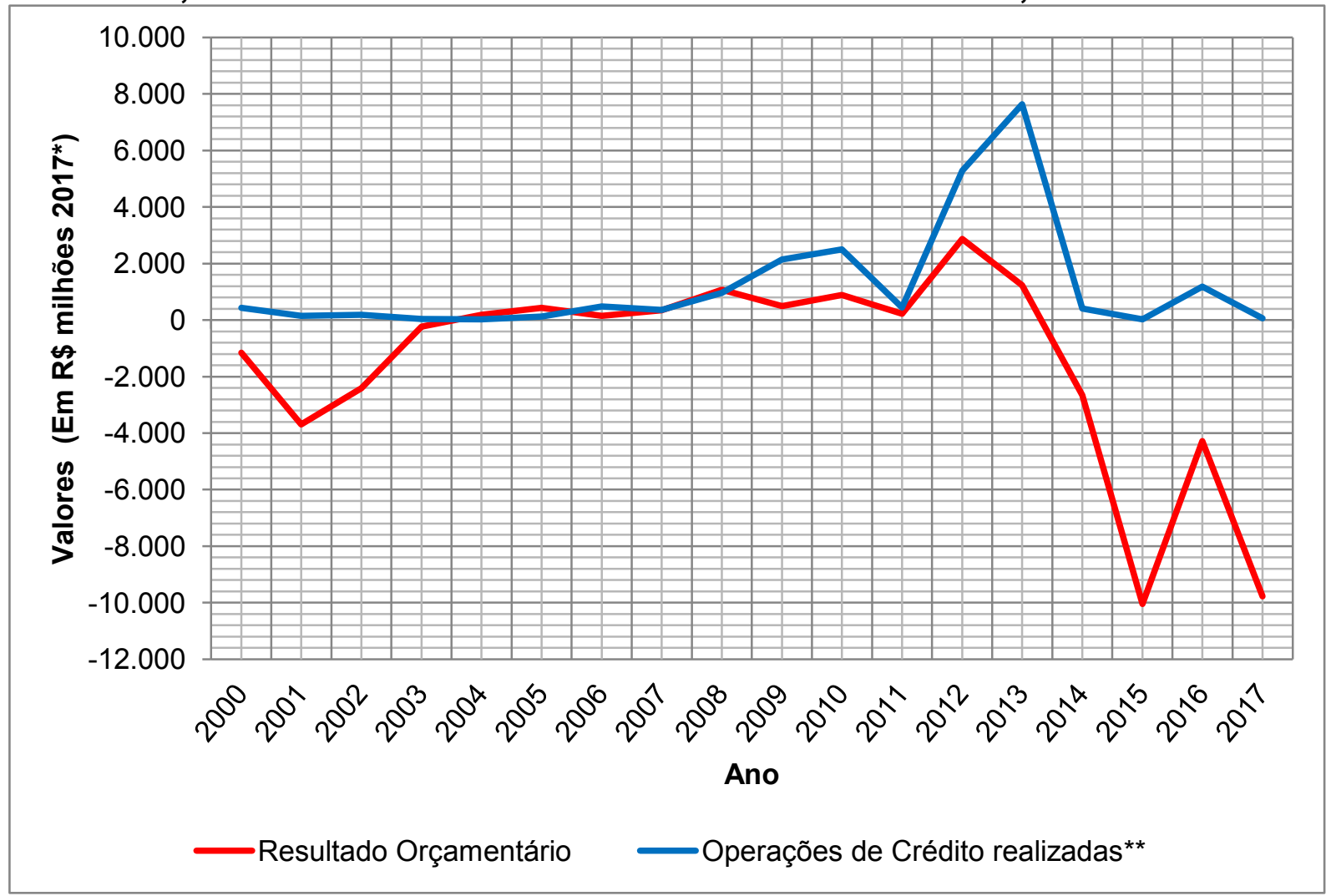

Fonte: Secretaria de Estado de Fazenda de Minas Gerais (2017).

(*) Dados ajustados pelo IPCA acumulado de 2017

$\left.{ }^{* *}\right)$ Inclui operações de crédito internas e externas

Mesmo com a contratação desses recursos e apresentando deficit, o RGF relativo ao último quadrimestre de 2014 mostra que o governo apresentava uma DCL de $178,79 \%$ da
RCL e se enquadrava nos limites estabelecidos pela LRF. Nesse percentual, destacou-se a dívida contratual (Gráfico 2). 


\section{Gráfico 2. Desempenho da dívida contratual e dívida consolidada líquida, Governo do Estado de Minas Gerais, 2003-2017}

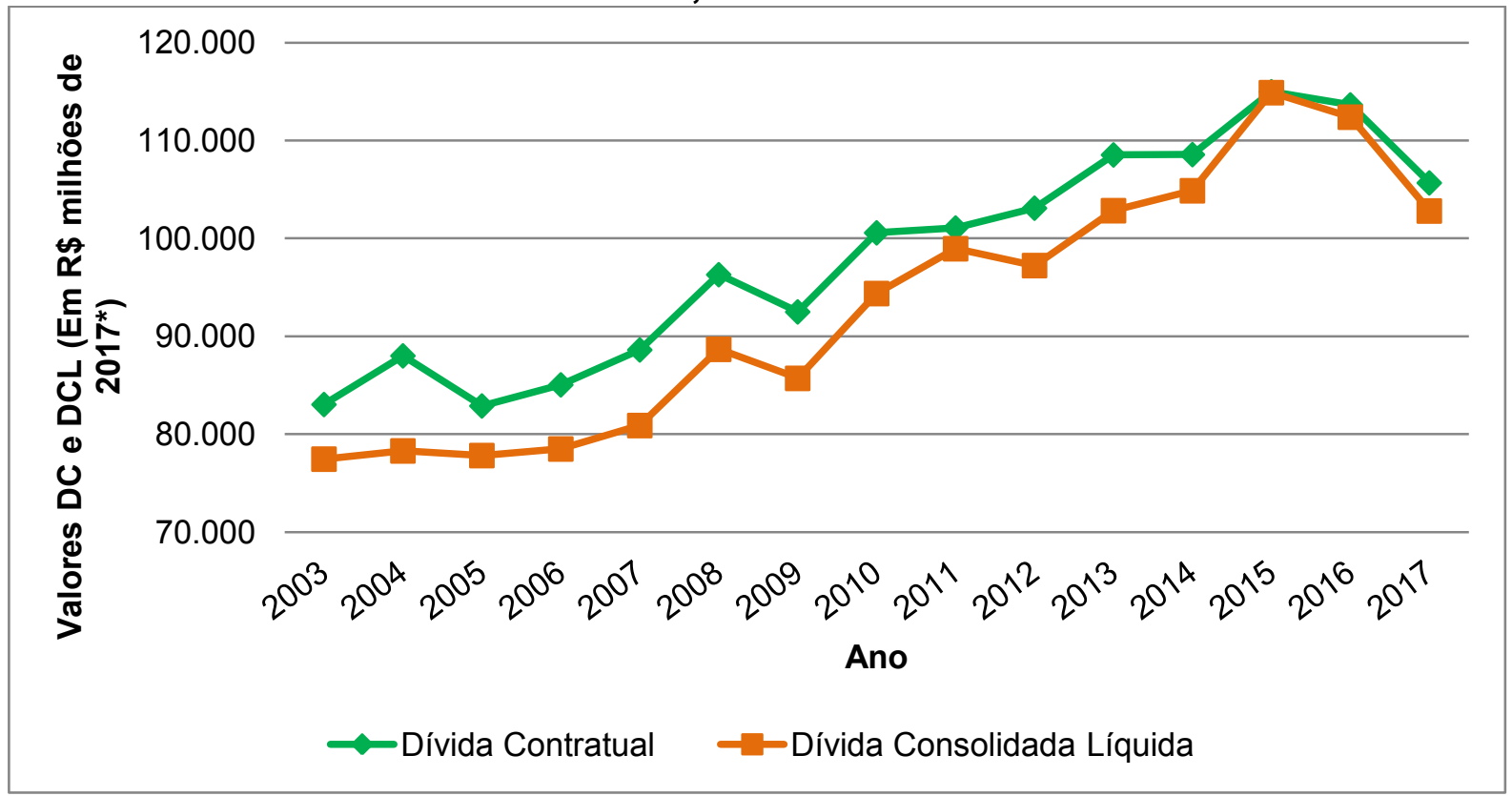

Fonte: Secretaria de Estado de Fazenda de Minas Gerais (2017).

(*) Dados ajustados pelo IPCA acumulado de 2017

Em 2015, Fernando Pimentel assumiu como governador com a proposta de investir em Fóruns Regionais para promover um melhor diálogo entre Estado e cidadãos. No entanto, o endividamento público ao final de 2016 já se enquadrava em níveis alarmantes, ultrapassando alguns limites legais, conforme mostram os RGFs publicados no período.

O primeiro limite, introduzido pela Resolução no 43/2001 do Senado Federal, estabeleceu em $200 \%$ o percentual permitido das $\mathrm{DCL}$ (que inclui as $\mathrm{OC}$ ) em relação à $\mathrm{RCL}$. A Resolução no 20/2001 do Senado Federal estabeleceu um limite contingencial para que os entes não sofressem de imediato as restrições previstas na legislação. Ela previu que o excesso da DCL apurado deveria ser reduzido em 15 anos, contados a partir de
2002, à proporção de um quinze avos a cada exercício financeiro (Senado Federal, 2001). No caso de Minas Gerais, essa proporção foi 2,30\% da DCL. Assim, o Estado esteve desenquadrado do limite por um período, mas se preservou das penalidades pela redução permitida.

O Gráfico 3 mostra o comportamento desse percentual ao longo dos anos. O estado conseguiu adequar-se aos limites em relação à DCL entre 2005 e 2006, o que permitiu seu retorno para o mercado de crédito. Em 2016, no entanto, Minas Gerais excede o limite, com o percentual de $203,09 \%$ da RCL, o que indicou a necessidade de ajustes financeiros e orçamentários. Em 2017, o Estado retornou ao limite permitido. 
Gráfico 3. Comportamento do percentual da dívida consolidada líquida em relação à receita corrente líquida, Governo do Estado de Minas Gerais, 2003-2017

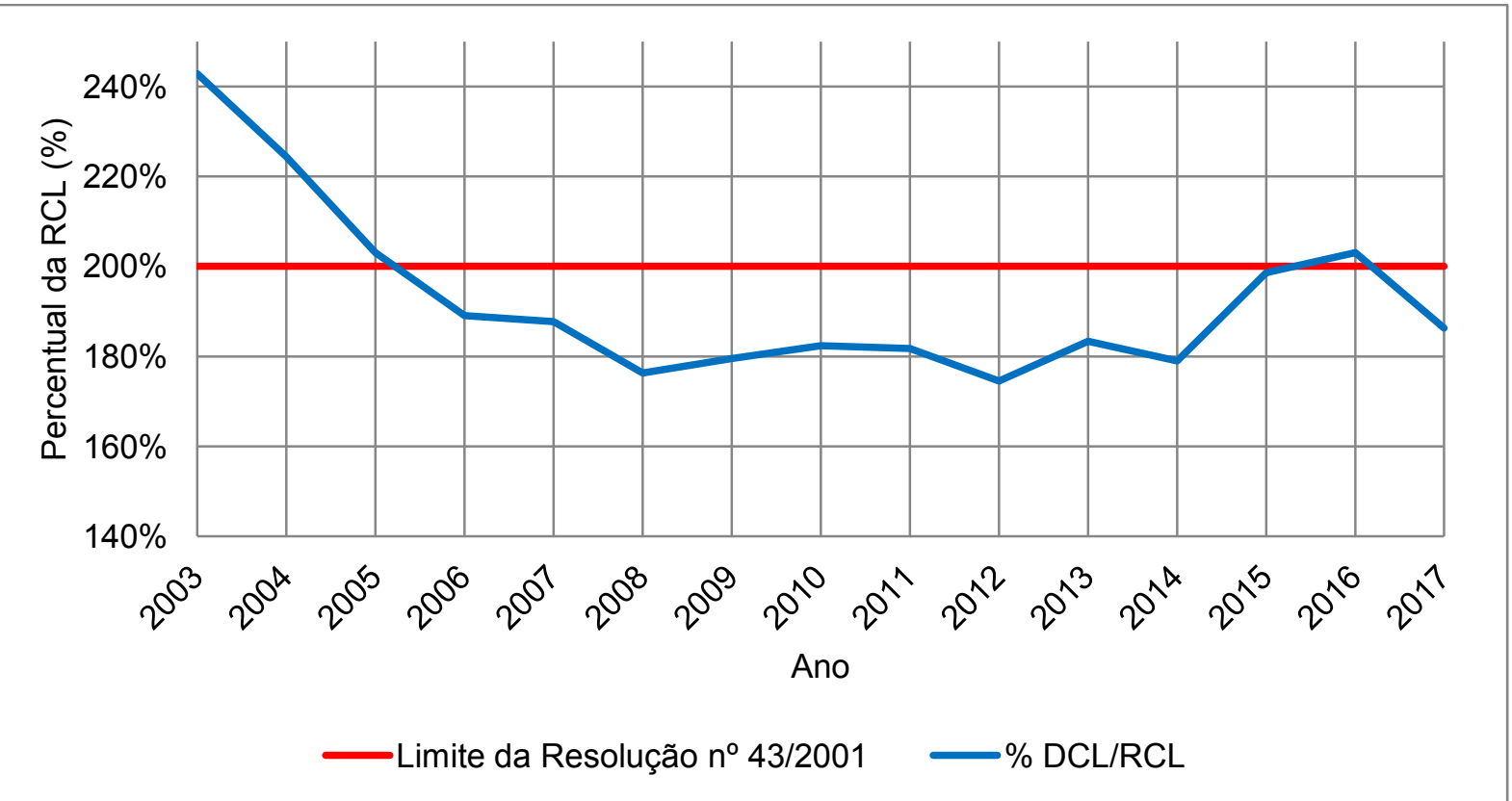

Fonte: Secretaria de Estado de Fazenda de Minas Gerais (2017).

O segundo limite determina que a despesa com pessoal do ente não pode ultrapassar $60 \%$ da RCL (LRF, art. 19). Contudo, cada poder possui limite individual. Para o Poder Executivo, o limite é de $49 \%$ da RCL. Caso seja ultrapassado por dois quadrimestres seguidos, o estado não poderá contratar OC.

O Gráfico 4 mostra os percentuais de gastos com pessoal em relação à $R C L$ registrados ao longo dos anos. O governo obteve percentuais muito próximos ao limite máximo, como em 2004 e 2010. No restante, manteve esse limite controlado, com exceção dos últimos anos. O último RGF divulgado mostrou que o gasto com pessoal atingiu o percentual de $50 \%$ e, assim, o Estado ficou legalmente impedido de contratar OC. 
Paula Guelman Davis - Isabella Virgínia Freire Biondini

\section{Gráfico 4. Comportamento do percentual da despesa com pessoal em relação à receita corrente líquida, Governo do Estado de Minas Gerais, 2003-2017}

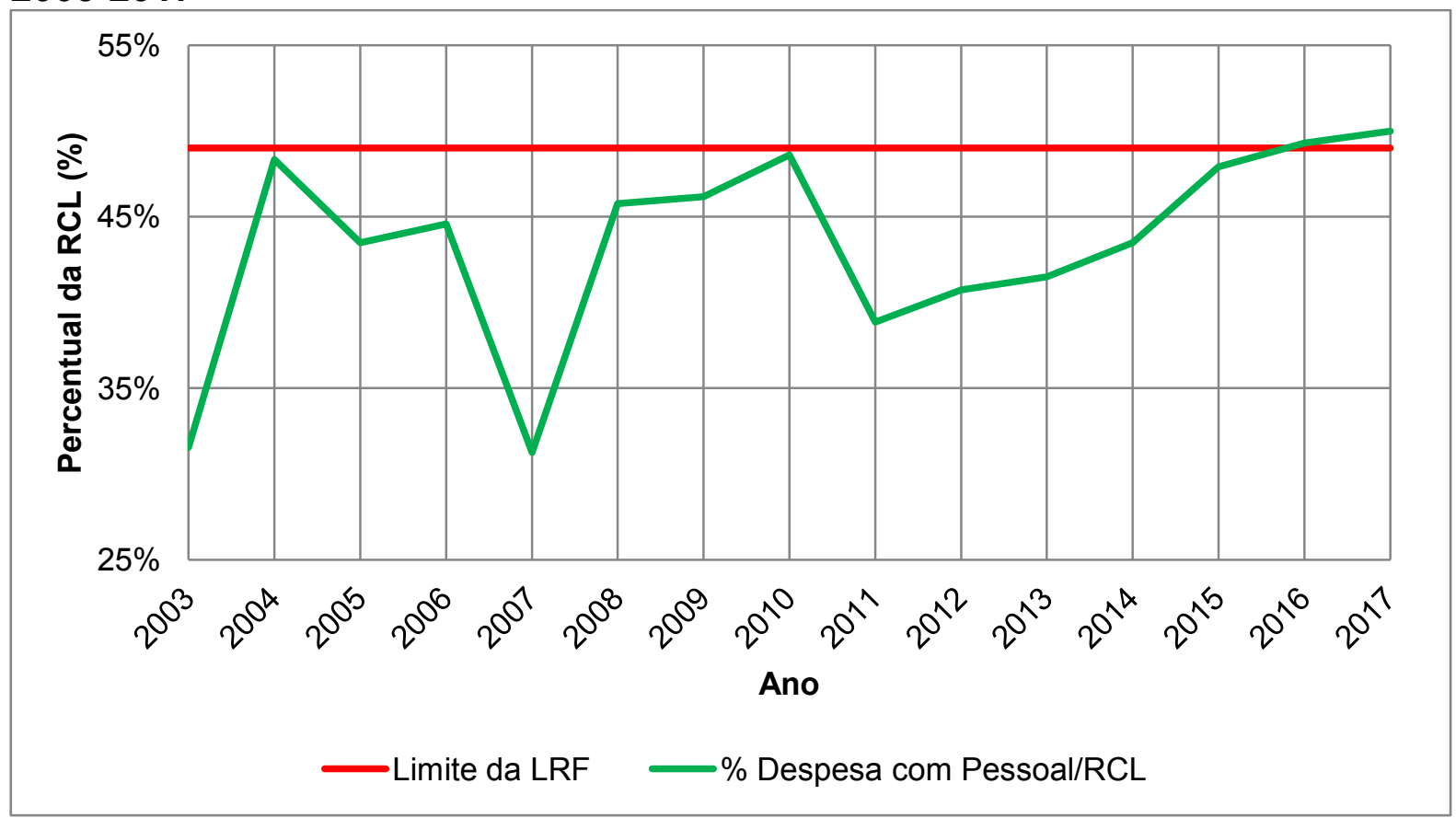

Fonte: Secretaria de Estado de Fazenda de Minas Gerais (2017).

Dada a piora nos resultados orçamentários em 2016, o governador sancionou o Decreto no 47.101/2016, declarando situação de calamidade financeira do Estado, sob as seguintes justificativas:

Art. 1ำ - Fica decretada a SITUAÇÃO DE CALAMIDADE FINANCEIRA no âmbito do Estado em razão do crescente déficit financeiro decorrente do histórico crescimento de despesas para as quais as receitas ordinárias, derivadas e transferidas têm sido insuficientes dado o severo momento econômico mundial e nacional que compromete a capacidade de investimento e custeio para a manutenção dos serviços públicos. (Assembleia Legislativa de Minas Gerais, 2016a, p. 2)

A introdução do decreto aponta o cresci- mento das despesas de pessoal efetivo, que não foi acompanhado por aumentos da RCL (conforme mostra o índice da LRF no Gráfico 5) (Assembleia Legislativa de Minas Gerais, 2016a).

A Assembleia Legislativa, ao longo do processo de aprovação da matéria, rejeitou duas emendas ao decreto. A primeira visava à proibição de gastos considerados supérfluos como solenidades, treinamento de servidores fora do estado, entre outros. A segunda objetivava estabelecer um prazo de 90 dias para vigência do decreto, no final do qual o governo deveria enviar um novo relatório de despesas para comprovar a necessidade de manutenção da legislação (Assembleia Legislativa de Minas Gerais, 2016b).

Desde então, o governo mineiro vem bus- 
cando alternativas para aumentar as receitas e reduzir a dívida pública. As principais serão detalhadas a seguir. No entanto, até o presente momento, não foi possível identificar melhoras significativas na situação financeira e fiscal do estado, considerando os resultados dos RGFs.

Observando o histórico do endividamento de Minas Gerais, é possível identificar a interferência dos juros e encargos da dívida no orçamento do estado. O Gráfico 5 traz os valores gastos com pagamento da dívida de 2001 a 2017. Em 2016, o governo registrou o menor pagamento com juros e encargos da dívida de todo o período. Segundo a SEF, isso ocorreu devido à renegociação da dívida do estado com a União, que autorizou o não pagamento de cerca de $R \$ 3$ bilhões no ano. Além disso, ocorreu a venda da folha de pagamento de pessoal para o Banco do Brasil, que rendeu $\mathrm{R} \$ 1,850$ bilhão ao Estado (Câmara dos Deputados, 2017).

Gráfico 5. Montante liquidado com juros e encargos da dívida pública, Governo do Estado de Minas Gerais, 2001-2017

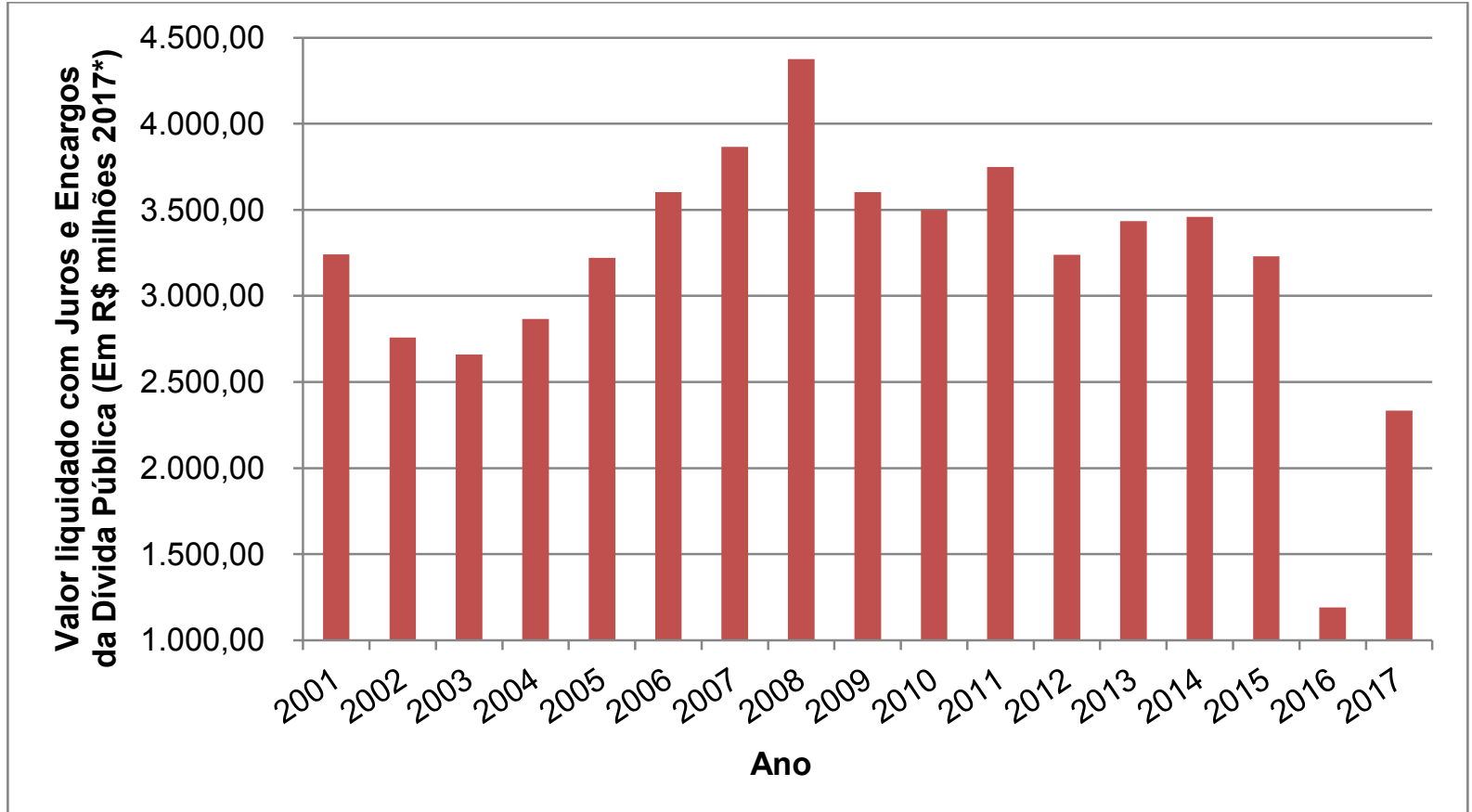

Fonte: Secretaria de Estado de Fazenda de Minas Gerais (2017).

$\left(^{*}\right)$ Dados ajustados pelo IPCA acumulado de 2017 
Em dezembro de 2017, a STN divulgou o Boletim de Finanças dos Entes Subnacionais. Nele, a sustentabilidade fiscal dos estados é avaliada por meio do cálculo da Capacidade de Pagamento (Capag) de cada um, considerando três indicadores: endividamento, poupança corrente e liquidez. A nota é dada por meio dos conceitos A, B, C e D. Se a combinação dos três indicadores apresentar conceito A ou B, o estado apresenta boa situação fiscal. Os conceitos $C$ e $D$, por sua vez, mostram o contrário, ou seja, o ente não apresenta condições financeiras adequadas para conseguir garantia da União para contratar empréstimos (Secretaria do Tesouro Nacional, 2017a).

Apenas dois estados conseguiram o conceito A na Capag: Espírito Santo e Pará. O Estado do Espírito Santo criou o Sistema Integrado de Gestão das Finanças Públicas (Sigefes), que modernizou a gestão financeira e orçamentária dos órgãos estaduais (Secretaria de Estado de Economia e Planejamento do Espírito Santo, 2016). O Estado do Pará, por sua vez, implementou, em 2015, o Sistema Integrado de Governança do Pará (Sigov) que contribuiu para a execução de medidas de racionalização das despesas públicas, adequando às receitas arrecadadas (Secretaria da Fazenda do Pará, 2017).

Os estados com pior desempenho foram Rio de Janeiro e Rio Grande do Sul. Cabe ressaltar que Minas Gerais, objeto deste artigo, não forneceu informações suficientes para que a STN conseguisse realizar o cálculo da Capag. No relatório de 2016, o Estado ficou no grupo com as piores notas (Secretaria do Tesouro Nacional, 2017a).

\section{AS RECENTES PROPOSTAS PARA RE-}

\section{CUPERAÇÃO DE MINAS GERAIS}

$\mathrm{Na}$ seção anterior, foi possível perceber o crescente comprometimento do orçamento público para questões voltadas à dívida. Dada a insolvência das contas públicas, o governo do Estado e a União vêm buscando obter algumas fontes alternativas de recursos, que serão detalhadas a seguir.

Acertos da Lei Kandir

A Emenda Constitucional no 42/2003, aceita pelo Supremo Tribunal Federal (STF) na Ação de Direta de Inconstitucionalidade por Omissão (ADI-O) no 25 movida pelo Estado do Pará, reconhece legalmente a necessidade da compensação das perdas referentes à Lei Kandir aos entes subnacionais. Deve-se ainda considerar que, ao longo de mais de 20 anos desde a promulgação da lei, as perdas se acumularam em valores muito altos.

Em abril de 2017, a Assembleia de Minas criou a Comissão Extraordinária entre Minas e a União, cujo objetivo era analisar as consequências da Lei Kandir. A promessa de compensação da perda de arrecadação de ICMS pela União não foi cumprida e acabou prejudicando muito o estado, que teve sua dívida aumentada. A Comissão defende um encontro de contas entre o valor devido por Minas Gerais à União e vice-versa. $O$ estado ainda permaneceria credor de $\mathrm{R} \$ 48,5$ bilhões que poderiam ser investidos pelo governo federal em obras de infraestrutura dentro do Estado (Assembleia Legislativa de Minas Gerais, 2017a).

O governador reuniu-se com outros chefes do executivo, tanto estaduais quanto municipais, visando pleitear o acerto da Lei Kandir. 
ENDIVIDAMENTO PÚBLICO DE MINAS GERAIS: HISTÓRICO E RECENTES PROPOSTAS DE RECUPERAÇÃo

Até o presente momento, as negociações com a União em relação ao repasse desses recursos não foram bem sucedidas (Agência Minas Gerais, 2017a).

Regime de Recuperação Fiscal dos Estados (RRFE)

governo federal publicou a Lei Complementar no 159/2017, com a intenção de fornecer instrumentos para o ajuste das contas, dados os graves desequilíbrios financeiros enfrentados pelos estados. Trata-se de uma complementação da LRF, que não previa meios para situações de insolvência fiscal (Secretaria do Tesouro Nacional, 2017b).
Para poder ingressar no RRFE, o Estado precisa declarar desequilíbrio financeiro a partir de três requisitos: RCL menor do que a DC ao final do último exercício; soma das despesas com pessoal e com juros e amortizações igual ou maior a $70 \%$ da RCL; e valor total de obrigações maior que as disponibilidades em caixa (Lei Complementar no 159, 2017). Além disso, o ente deve apresentar um Plano de Recuperação Fiscal, incluindo um conjunto de leis (Figura 2), um diagnóstico comprovando a situação de grave desequilíbrio, e detalhamento das medidas de ajustes, com indicação de impactos esperados e prazos definidos (Lei Complementar no 159, 2017).

\section{Figura 2. Leis exigidas pela Lei Complementar $n^{\circ}$ 159, Brasil, 2017}
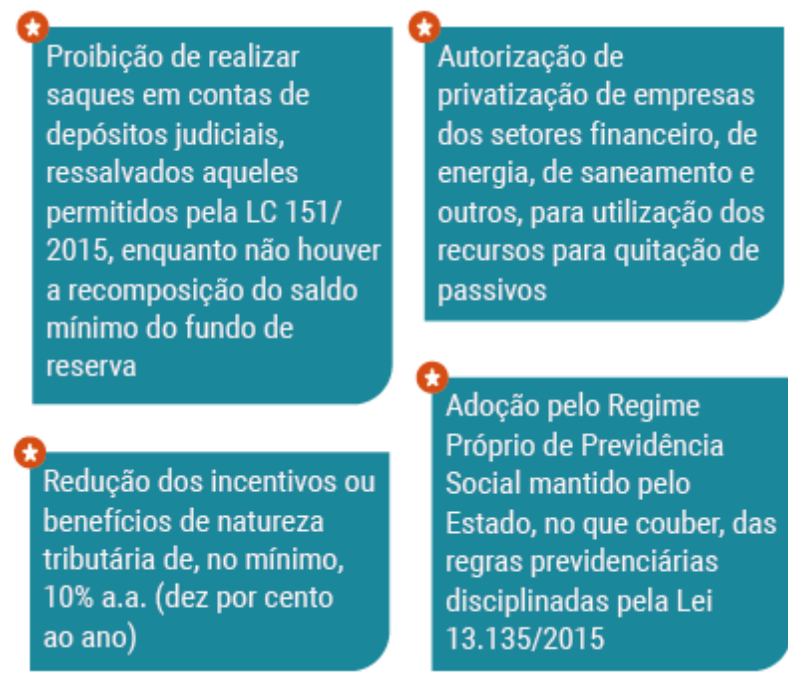

Fonte: Tesouro Nacional (2017).

No período de duração do RRFE, são assegurados ao Estado alguns instrumentos, como a suspensão temporária de requisitos legais para contratar OC e de sanções relativas ao descumprimento dos limites da LRF sobre despesa com pessoal e dívida consolidada. Contudo, o Regime também veda o retorno de algumas ações estatais que aumentem as despesas, como a con-
Revisão do regime jurídico único dos servidores

estaduais da

administração pública ou

aprovação de lei para

disciplinar o crescimento

das despesas obrigatórias (teto de gastos)

Instituição, se cabível, do regime de previdência complementar a que se referem os $\S \S 14,15$ e 16 do art. 40 da Constituição Federal

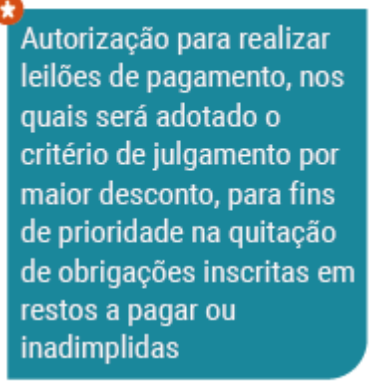

inadimplidas cessão de reajustes a servidores, admissão ou contratação de pessoal, realização de despesas com publicidade e propaganda (exceto as de utilidade pública), entre outras (Lei Complementar no 159, 2017). Até o presente momento, Minas Gerais não aderiu ao RRFE; os únicos estados que o fizeram foram Rio de Janeiro e Rio Grande do Sul (Secretaria do Tesouro Nacional, 2017b). 


\section{Criação de Fundos Estaduais}

Com o objetivo de ampliar a disponibilização de recursos, o governo do Estado elaborou o Projeto de Lei no 4.135/17, que propunha seis fundos estaduais de incentivo e financiamento de investimentos: (1) Fundo de Investimento do Estado de Minas Gerais (MG Investe); (2) Fundo de Pagamento de Parcerias Público-Privadas (FPP-MG); (3) Fundo de Garantias de Parcerias Público-Privadas (FGP-MG); (4) Fundo Especial de Créditos Inadimplidos e Dívida Ativa (Fecidat); (5) Fundo de Ativos Imobiliários de Minas Gerais (Faimg); e (6) Fundo de Investimentos Imobiliários de Minas Gerais (Fiimg). $\mathrm{O}$ projeto de lei foi aprovado com veto parcial e, em julho de 2017, foi publicada a Lei no 22.606 (Assembleia Legislativa de Minas Gerais, 2017b)

No que diz respeito à dívida pública, os fundos MG Investe, FPP-MG e FGP-MG podem ser utilizados para amortizar dívidas contraídas por meio de OC internas ou externas destinadas a eles, desde que isso não prejudique a execução dos programas planejados (Lei no 22.606, 2017).

O Fecidat visa promover melhorias na gestão de ativos e receitas do Estado. A receita viria da cobrança dos créditos inadimplidos inscritos, da venda dos ativos de natureza sênior e dos rendimentos e frutos decorrentes da aplicação dos recursos.. Os fundos imobiliários, por sua vez, foram criados para aproveitamento econômico dos imóveis do Estado (Lei no 22.606, 2017).

\section{Securitização}

Em dezembro de 2017, o Projeto de Lei no 204/2016, que autoriza os entes federados a realizarem a prática de securitização, foi aprovado no Senado Federal. Essa prática consiste na venda do direito dos créditos que o poder público tem a receber, sejam de origem tributária ou não. No entanto, o ente deve estar disposto a aceitar um desconto no valor a receber (Senado Federal, 2017b).

Segundo a Agência Minas, portal de notícias do governo, Minas tem cerca de $\mathrm{R} \$ 5$ bilhões em dívida ativa. Caso a securitização seja aprovada, estima-se que cerca de $\mathrm{R} \$ 2,5$ biIhões ingressem nas contas públicas (Agência Minas Gerais, 2017b).

O Projeto de Lei Complementar no 459/2017 já foi aprovado pela Comissão de Assuntos Econômicos (CAE) e aguarda a realização de Audiência Pública requerida pelo relator na Comissão de Finanças e Tributação (CFT) da Câmara Federal desde o dia 13 de junho de 2018. Cabe frisar que o projeto apresenta algumas ressalvas, como autorização do Poder Legislativo, preservação da natureza do crédito, não alteração de valores, datas e condições de pagamento, entre outros (Senado Federal, 2017b).

\section{CONSIDERAÇÕES FINAIS}

A dívida pública, conforme apresentada neste artigo, pode ser avaliada usando uma série de variáveis e indicadores, que conseguem demonstrar que o ente não está conseguindo arcar com seus compromissos de maneira autossuficiente. Ao buscar um financiamento, o governo deve estar ciente de que terá que pagar mais do que recebeu, devido aos encargos e juros da dívida. Contudo, se esse processo ocorre de maneira desorde- 
nada, ele pode gerar consequências futuras, como a insolvência.

A contratação de empréstimos pelos estados, que se iniciou na década de 1960, ocorreu de maneira tão desordenada que foram necessários vários acordos de renegociação das dívidas, além dos controles normativos que persistem até hoje. Além disso, revelou constantes impasses entre União e entes subnacionais.

A partir do histórico do endividamento de Minas Gerais, foi possível perceber que, assim como em outros estados, o crescimento da dívida, principalmente após 1994, iniciou o processo de comprometimento do orçamento público. As OC eram contratadas para complementar as receitas públicas, de modo a financiar investimentos para promover o crescimento econômico do estado, visto que o orçamento se mostrava constantemente comprometido por encargos da dívida, e terminaram por contribuir com o endividamento e com o crescimento das despesas com juros e amortizações.

De maneira geral, os governantes não se preocuparam muito com a escolha de caminhos sustentáveis para as finanças públicas do Estado, uma vez que a aplicação de recursos está subordinada à vontade política. Minas Gerais, cuja dívida encontra-se em expansão desde a década de 1990, é prova de que os indicadores de endividamento não são, geralmente, levados em conta no momento em que as ações são planejadas e executadas. Apesar dos grandes montantes de juros e encargos pagos todos os anos, as Administrações continuam insistindo em financiamentos onerosos tanto para o presente quanto para o futuro.
No entanto, em situações de dívida elevada, é preciso que um percentual da receita tributária seja destinado a atividades que promovam retorno financeiro ao estado, de modo a compensar o dispêndio, gerar crescimento econômico e conseguir pagar parcelas da dívida.

Nos últimos anos, a situação financeira do Estado tornou-se insustentável, dada a extrapolação dos limites da LRF. O decreto de calamidade financeira, alternativa encontrada pelo governo para atenuar as sanções dessa lei, não é, de fato, uma solução. Como não foi estabelecido um prazo para o decreto, as finanças podem sair do controle e complicar ainda mais a situação no futuro. O ideal seria implementar paralelamente ações concretas para limitação das despesas, como a redução de despesas com pessoal, principalmente cargos em comissão de recrutamento amplo, renegociação de contratos, redesenho de processos excessivamente burocráticos etc.

Devido à insustentabilidade das contas, 0 governo do Estado ficou engessado e teve que priorizar a busca por fontes alternativas de financiamento. Porém, no que se pode verificar, nenhuma delas teve impacto significativo: as compensações da Lei Kandir são uma disputa entre a União e os entes subnacionais; o RRFE impõe restrições que prejudicariam a autonomia da atual Administração; os fundos estaduais são recentes e, até onde foi possível verificar, ainda não geraram resultados significativos; a securitização, por fim, ainda é incerta. No entanto, essa última alternativa, mesmo resultando numa antecipação de receita, pode gerar perdas importantes ao Estado, devido ao 
desconto nos valores a receber.

Por fim, este artigo mostrou que, desde a década de 1990, no processo de tomada de decisão dos governantes, a dívida nem sempre foi considerada e, por isso, Minas Gerais encontra-se hoje em situação de calamidade financeira e precisa de soluções rápidas que garantam a recuperação econômica do Estado.

Nesse sentido, acredita-se na importância da interlocução do Estado com outros entes subnacionais, buscando boas práticas implementadas na gestão financeira, como o Sigefes no Espírito Santo. Com administradores públicos técnicos, seria possível adaptar essas práticas para Minas Gerais, melhorando os bancos de dados financeiros, os indicadores e relatórios.

As limitações do trabalho envolvem o número limitado de referências recentes e específicas sobre as finanças do Estado de Minas Gerais, além dos dados obtidos somente pelos relatórios governamentais prontos. Futuras pesquisas podem realizar uma análise comparativa da gestão fiscal dos estados, utilizar técnicas de mineração de dados para verificar a existência de padrões no dispêndio público nas diversas áreas de atuação estatal, verificar a eficiência do RRFE na recuperação dos estados, entre outros.

\section{REFERÊNCIAS}

Agência Minas Gerais. (2017a, Outubro 16). Fernando Pimentel defende encontro de contas imediato para ressarcimento de perdas fiscais da Lei Kandir. [Post da web]. Recuperado de http://www.agenciaminas. mg.gov.br/noticia/fernando-pimentel-defen- de-encontro-de-contas-imediato-para-ressarcimento-de-perdas-fiscais-da-lei-kandir

Agência Minas Gerais. (2017b, Março 30). Fernando Pimentel encaminha à Assembleia projetos de lei para alavancar a economia do Estado. [Post da web]. Recuperado de http:// www.agenciaminas.mg.gov.br/noticia/fernando-pimentel-encaminha-a-assembleia-projetos-de-lei-para-alavancar-a-economia-do-estado-2017-03-30-15-30-00-0300

Almeida, A. O. (1996). Evolução e crise da dívida pública estadual. Texto Para Discussão 448 (pp. 1-48). Brasília, DF: Instituto de Pesquisa Econômica Aplicada (IPEA). Recuperado de http://www.ipea. gov.br/portal/index.php?option=com content\&view=article\& $i d=3644$

Assembleia Legislativa de Minas Gerais. (2016a). Decreto $n^{\circ} 47.101$, de 5 de dezembro de 2016: Decreta situação de calamidade financeira no âmbito do Estado. Recuperado de https://www.almg.gov.br/consulte/legislacao/completa/completa.html?tipo=DEC\&nu $\mathrm{m}=47101$ \&ano $=2016$

Assembleia Legislativa de Minas Gerais. (2016b, Dezembro 7). Plenário aprova projeto que reconhece calamidade financeira: Governo do Estado alega aumento de despesas e redução de receitas em meio à crise econômica. [Post da Web]. Recuperado de https://www.almg.gov.br/acompanhe/noticias/arquivos/2016/12/07_plenario_projeto_ calamidade_financeira.html

Assembleia Legislativa de Minas Gerais. (2017a). Comissão Extraordinária de Acerto de Contas entre Minas e a União: Relatório Final. Belo Horizonte, MG. Recuperado de ht- 
tps://www.almg.gov.br/hotsites/2017/acerto-de-contas/index.html?albPos=1\&aba=js_ comissao-extraordinaria

Assembleia Legislativa de Minas Gerais. (2017b). Proposições de Repercussão: Projeto de Lei (PL) 4.135/17 - Fundos de Investimentos. Recuperado de https://www.almg. gov.br/sala_imprensa/proposicoes_de_repercussao/PL_4135_2017/?action=search\& searchPage $=1 \&$ aba $=$ js_tabTramitacao

Câmara dos Deputados. (2017). PLP 459/2017: Projeto de Lei Complementar. Recuperado de http://www.camara.gov.br/ proposicoesWeb/fichadetramitacao?idProp osicao $=2166464$

Cruz, F., Vaccari Junior, A., Glock, J. O., Herzmann, N. \& Tremel, Rosângela (2014). Lei de Responsabilidade Fiscal Comentada: Lei Complementar $n^{\circ} 101$, de 4 de maio de 2000 (9a ed.). São Paulo, SP: Atlas S.A.

Freitas, C. M. (2014). Orçamento público: Uma análise das operações de crédito, do endividamento e dos investimentos públicos no Estado de Minas Gerais no período 2003-2014 (Trabalho de conclusão de curso, Escola de Governo Professor Paulo Neves de Carvalho - Fundação João Pinheiro - Belo Horizonte, MG).

Lei oㅡ 22.606, de 20 de julho de 2017. (2017). Cria fundos estaduais de incentivo e de financiamento de investimento e dá outras providências. Belo Horizonte, MG. Recuperado de https://www.almg.gov.br/consulte/ legislacao/completa/completa-nova-min.ht $\mathrm{ml}$ ?tipo $=$ LEl\&num $=22606 \&$ comp $=\& a n o=20$ 17\&texto $=$ consolidado
Lei Complementar no 159, de 19 de maio de 2017. (2017). Institui o Regime de Recuperação Fiscal dos Estados e do Distrito Federal e altera as Leis Complementares no 101, de 4 de maio de 2000, e no 156, de 28 de dezembro de 2016. Brasília, DF. Recuperado de http://www.planalto.gov.br/ccivil_03/leis/ Icp/lcp159.htm

Lopreato, F. L. C. (2002). O colapso das finanças estaduais e a crise da federação. (Coleção Economia Contemporânea). São Paulo, SP: Unesp.

Lopreato, F. L. C. (2004). A situação financeira dos Estados e a reforma tributária (pp. 1-23). Texto para Discussão n. 115. Campinas, SP: IE/Unicamp. Recuperado de http:// www.eco.unicamp.br/docprod/downarq. php? $i d=1745 \&$ tp $=a$

Matias-Pereira, J. (2017). Finanças públicas (7a ed.). São Paulo, SP: Atlas.

Mendonça, F. (2005). A dívida pública brasileira. Brasília, DF: Plenarium.

Mora, M. (2002). Federalismo e dívida estadual No Brasil. Texto para Discussão n. 866. Rio de Janeiro, RJ: IPEA: Instituto de Pesquisa Econômica Aplicada. Recuperado de http://www.ipea. gov.br/portal/index.php?option=com content\&view $=$ article\& $i d=4409$

Motta, C. P. C., \& Fernandes, J. U. J. (2001). Responsabilidade fiscal: Lei Complementar 101 de 4/5/2000 (2a ed.). Belo Horizonte, MG: Del Rey.

Oliveira, F. A. (2007). Teorias da federação e do federalismo fiscal: $O$ caso brasileiro. 
Texto para discussão n. 43. Belo Horizonte, MG: Escola de Governo/Fundação João Pinheiro.

Oliveira, F. A. De, \& Gontijo, C. (2012). Dívida pública do estado de Minas Gerais: A renegociação necessária. Belo Horizonte, MG: [s.n.].

Oliveira, F. A. De, \& Riani, F. (2004). Limitações e consequências do ajuste fiscal do estado de Minas Gerais no governo Aécio Neves. XI Seminário sobre Economia Mineira, Diamantina, MG. Recuperado de https:// core.ac.uk/download/pdf/6520214.pdf

Rezende, A. M. R. T., Carneiro, R., \& Rezende, J. V. S. (2014). Federalismo fiscal e crise das finanças públicas no Brasil: Uma análise de indicadores fiscais nos Estados de 2007 a 2012. XXXVIII Encontro da ANPAD, Rio de Janeiro, RJ. Recuperado de http://www.anpad.org.br/admin/pdf/2014_ EnANPAD_APB2208.pdf

Rezende, F. (2012). Finanças públicas (2a ed.). São Paulo, SP: Atlas.

Riani, F., \& Andrade, S. M. M. (2002). Evolução recente e a renegociação da dívida pública do Estado de Minas Gerais. X Seminário sobre Economia Mineira, Diamantina, MG. Recuperado de https://core.ac.uk/ download/pdf/6519811.pdf

Secretaria da Fazenda do Pará. (2017). Pará teve um dos melhores desempenhos fiscais no Brasil em 2016. Recuperado de http://www.sefa.pa.gov.br/index.php/ noticias/12981-para-teve-um-dos-melhores-desempenhos-fiscais-no-brasil-em-2016-aponta-stn
Secretaria de Estado de Economia e Planejamento do Espírito Santo. (2016). Sistema de Gestão de Finanças do Espírito Santo é referência para outros Estados. Portal do Governo do Espírito Santo. Recuperado de https:// planejamento.es.gov.br/Not\%C3\%ADcia/ sistema-de-gestao-de-financas-do-espirito-santo-e-referencia-para-outros-estados

Secretaria de Estado de Fazenda de Minas Gerais (Org.). (2006). As contas públicas de Minas de 2003 a 2006: A história do "déficit zero". Belo Horizonte, MG: Imprensa Oficial do Governo de Minas Gerais.

Secretaria de Estado de Fazenda de Minas Gerais. (2014). Demonstrações contábeis do Estado. Belo Horizonte, MG: Superintendência Central de Contadoria Geral (SCCG). Recuperadas de http://www.fazenda.mg.gov. br/governo/contadoria_geral/relatorio_contabil

Secretaria de Estado de Fazenda de Minas Gerais. (2017). Minas Gerais registra déficit fiscal de R\$ 4,1 bilhões em 2016: Medidas adotadas pelo Governo contribuíram para aumento da arrecadação e redução das despesas [Post da web]. Recuperado de http:// www.fazenda.mg.gov.br/noticias/2017.01.31_ RGF.html

Secretaria do Tesouro Nacional. (2017a). Boletim de Finanças dos Entes Subnacionais. Brasília, DF: Ministério da Fazenda. Recuperado de http://www.tesouro.fazenda.gov.br/-/ boletim-de-financas-dos-entes-subnacionais-2017

Secretaria do Tesouro Nacional. (2017b). Regime de Recuperação Fiscal. Recuperado 
de http://www.tesouro.fazenda.gov.br/rrf\#O que é o Regime de Recuperação Fiscal

Senado Federal. (2001). Resolução $n^{\circ} 40$ de 2001. Dispõe sobre os limites globais para - montante da dívida pública consolidada e da dívida pública mobiliária dos Estados, do Distrito Federal e dos Municípios, em atendimento ao disposto no art. 52, VI e IX, da Constituição Federal. Brasília, DF: Secretaria de Informação Legislativa. Recuperado de http://www2.camara.leg.br/legin/ fed/ressen/2001/resolucao-40-20-dezembro-2001-429320-normaatualizada-pl.html

Senado Federal. (2017a, Maio 17). Senado aprova projeto de socorro financeiro aos estados [Post da web]. Agência Senado. Recuperado de https://www12.senado.leg. $\mathrm{br} /$ noticias/materias/2017/05/17/senado-aprova-projeto-de-socorro-financeiro-aos-estados

Senado Federal. (2017b, Dezembro 13). Senado aprova a securitização de dívidas de entes federados [Post da web]. Redação Senado Notícias. Recuperado de https://www12.senado.leg.br/noticias/ materias/2017/12/13/senado-aprova-a-securitizacao-de-dividas-de-entes-federados
Silva, A. C., Carvalho, L. O. de, \& Medeiros, O. L. de. (2009). Dívida pública: A experiência brasileira. Brasília, DF: Secretaria do Tesouro Nacional: Banco Mundial.

Silva, I. F. B. R. (2002). Endividamento subnacional em um contexto federativo: $O$ caso brasileiro. Cadernos de Finanças Públicas - Escola de Administração Fazendária (ESAF), 3(3), 59-126. Recuperado de http:// www.esaf.fazenda.gov.br/assuntos/biblioteca/cadernos-de-financas-publicas

Soares, M. R. da C. (2007). Lei Kandir: Breve histórico. Brasília, DF: Consultoria Legislativa - Câmara dos Deputados. Recuperado de http://www2.camara.leg.br/a-camara/documentos-e-pesquisa/estudos-e-notas-tecnicas/areas-da-conle/tema20/2007_12856. pdf

Vilhena, R., Martins H. F., Marini, C. \& Guimarães, T. B. (Orgs.) (2006). O choque de gestão em Minas Gerais: Políticas da gestão pública para o desenvolvimento. Belo Horizonte, MG: Editora UFMG. 